\title{
Potentiality of Native Pseudomonas spp. in Promoting Sugarcane Seedling Growth and Red Rot (Colletotrichum falcatum went) Management
}

\author{
P. Kishore Varma* , K.V.K. Kumar, M. Suresh, N. Raja Kumar and V.C. Sekhar \\ Regional Agricultural Research Station, Anakapalli, Visakhapatnam, \\ Andhra Pradesh-531001, India \\ *Corresponding author
}

\section{A B S T R A C T}

\begin{tabular}{|c|}
\hline Keywords \\
\hline $\begin{array}{l}\text { Biological control, } \\
\text { Colletotrichum, } \\
\text { PGPR, Pseudomonas, } \\
\text { Red rot }\end{array}$ \\
\hline Article Info \\
\hline $\begin{array}{l}\text { Accepted: } \\
\text { 24 January } 2018 \\
\text { Available Online: } \\
10 \text { February } 2018\end{array}$ \\
\hline
\end{tabular}

Eight native strains of Pseudomonas spp. were isolated from rhizosphere of various sugarcane clones on Pseudomonas agar using standard protocols. These strains were characterized for antagonistic traits on red rot pathogen in vitro and Plant growthpromoting (PGP) activities in greenhouse up to 30 days from single node setts in portrays

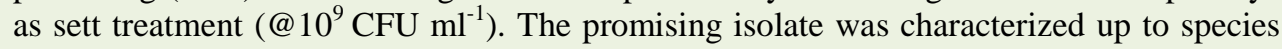
level by PCR amplification of $16 \mathrm{~S}$ rDNA region using Pseudomonas specific primers. Elite strain was identified as $P$. putida strain AKP-1. Our results indicated that, Pseudomonas strains were inhibitory to $C$. falcatum (1.4 to $69.2 \%$ inhibition). Majority of isolates produced catalase, protease and $\mathrm{HCN}$; however, only few isolates were IAA producers and phosphate solubilizers. In Greenhouse, all the isolates were found to enhance sugarcane seedling growth, however, the $P$. putida strain AKP-1 was found superior over others. Our future studies are directed in establishing the endophytic nature, if any, of these elite strains in sugarcane and in confirming the antagonistic activity on $C$. falcatum in GH and field besides PGP activities.

\section{Introduction}

Sugarcane is an important cash crop grown in tropical and sub-tropical regions of the world. India is the second largest producer of sugar after Brazil and accounts for 16 per cent of world production (GOI, 2015). In Andhra Pradesh, sugarcane is grown in 1.39 lakh hectares with a production of 99.8 lakh tones. However, the sugarcane productivity (71 tonnes/ha) is very low compared to states like Tamil Nadu, West Bengal, Kerala and Karnataka (GOI, 2017). Sugarcane productivity in Andhra Pradesh is majorly hampered by several biotic stresses of which red rot caused by the fungus, Colletotrichum falcatum Went, is a serious threat to sugarcane production under irrigated conditions. The pathogen infects mature stalks of sugarcane; leaf midribs and cause rot of planting material which results in substantial losses in crop yield and sugar quality (Rao, 2004). This disease is responsible for phasing out of several ruling cultivars previously.

Various approaches like cultural methods, use of chemicals, biocontrol agents and thermotherapy were in vogue for the 
management of sugarcane red rot. Some bioagents like Trichoderma harzianum, $T$. viride and Pseudomonas species were found promising in the management of red rot of sugarcane by reducing soil borne inoculum of C. falcatum (Singh et al., 2008; Hassan et al., 2011). Red rot of sugarcane is primarily a sett borne disease that is disseminated through infected setts and irrigation water.

The use of seedlings raised in portrays through single noded setts is gaining popularity among the farmers and the seed rate used per acre is reduced from 4 tonnes to 1 ton enabling sett treatment with fungicides and bioagents. Our present research is aimed at identifying a potential Plant Growth-Promoting Rhizobacterial (PGPR) strain that promotes seedling growth besides managing red rot disease effectively.

\section{Materials and Methods}

\section{Isolation of Pseudomonas species from} sugarcane rhizosphere

Soil samples were collected from the rhizosphere of sugarcane clones, CoA13326, 2001A63, 87A298, CoA13324, Co6907, CoV92102 and CoA13322, during winter 2015. The rhizospheric bacteria were isolated on Pseudomonas agar medium (HiMedia) by serial dilution method. The colonies with different morphology were selected, purified and maintained on Luria Bertani Agar medium.

\section{Identification of elite Pseudomonas species}

The bacterial isolates were multiplied in Luria Bertani broth overnight and the DNA was extracted according to the protocol given by Sambrook and Russell (2001). PCR was performed in a volume of $25 \mu \mathrm{l}$ containing 1 $\mu 1$ of DNA template, $2.5 \mu \mathrm{l}$ of $10 \mathrm{X}$ PCR buffer, $1 \mu \mathrm{l}$ of each dNTP, $2 \mathrm{mM}$ of $\mathrm{MgCl}_{2}, 1$ $\mu l$ of each primer and $0.5 \mathrm{U}$ of Taq Polymerase. The 16S rDNA amplification was performed using the primers Psmn 289 (5'GGTCTGAGAGGATGATCAGT-3') and Psmn 1258 (5'-TTAGCTCCACCTCGCGGC3'). PCR was performed on Master Cycler Nexus Gradient (Eppendorf, USA). PCR programme was $5 \mathrm{~min}$ at $95^{\circ} \mathrm{C} ; 30$ cycles of $30 \mathrm{~s}$ at $94^{\circ} \mathrm{C}, 30 \mathrm{~s}$ at $53^{\circ} \mathrm{C}$, and $1 \mathrm{~min}$ at $72^{\circ} \mathrm{C}$; and a final extension for $10 \mathrm{~min}$ at $72^{\circ} \mathrm{C}(\mathrm{Kim}$ et al., 2013).

Following amplification $25 \mu \mathrm{l}$ product were analyzed by electrophoresis at $100 \mathrm{~V}$ in $(1 \%$ agarose gel, $0.2 \mu \mathrm{g}$ of ethidium bromide $\mathrm{ml}^{-1}$ ) TAE buffer. Ethidium bromide (Ebr) stained agarose gels were observed on UV transilluminator and the amplified product was excised from the gel and sent for sequencing to Bioserve technologies, Hyderabad. The nucleotide sequence data obtained was subjected to NCBI BLAST search and the sequences thus identified were submitted to NCBI and accession numbers were obtained.

\section{Antagonistic activity of Pseudomonas species against Colletotrichum falcatum}

The antagonistic properties of Pseudomonas species were tested against $C$. falcatum on PDA plates by using dual culture technique. For testing the antagonistic potential of Pseudomonas species., an agar block $(5 \mathrm{~mm}$ diameter) of 5-day-old culture of test pathogen was placed in the centre of Petri plates $(90$ mm diameter) containing PDA. A loopful of 24-h-old culture of Pseudomonas species was streaked on either sides of $C$. falcatum disc at a distance of $2 \mathrm{~cm}$ apart. The fungal pathogen culture inoculated centrally on PDA plates, but un-inoculated by bacterial isolates served as control. Each treatment was replicated thrice and the inoculated plates were incubated at $25 \pm 10 \mathrm{C}$ for 5 days and per cent inhibition was calculated as per the following formula given by Dennis and Webster (1971). 


\section{Determination of catalase activity}

The Catalase activity was determined by adding few drops of $3 \%(\mathrm{v} / \mathrm{v}) \mathrm{H}_{2} \mathrm{O}_{2}$ to $5 \mathrm{ml}$ of 18 hours grown bacterial cultures in LuriaBertani broth (Kannan, 2002).

\section{Qualitative test for protease activity}

All bacterial isolates were screened for protease activity by inoculating on skim milk agar plates. Plates were incubated at $28+1^{\circ} \mathrm{C}$ for 72 hours and observed for proteolysis, i.e., clear zone production around the inoculated bacterial disc.

\section{Qualitative determination of phosphate solubilisation}

Phosphate solubilization ability of bacterial isolates was detected by inoculating them on Pikovaskaya's agar plates (Pikovaskaya, 1948). The inoculated plates were incubated at $28+1^{0} \mathrm{C}$ for 3 days and observed for appearance of clearing zone around the colonies.

\section{Qualitative test for $\mathrm{HCN}$ production}

HCN production was determined by modified method of Bakker and Schippers (1987). Exponentially grown cultures of bacterial isolates were streaked on to Luria-Bertani agar plates supplemented with $4.4 \mathrm{~g}$ glycine $\mathrm{L}^{-1}$. Simultaneously, a filter paper soaked in $0.5 \%$ picric acid in $1 \% \mathrm{Na}_{2} \mathrm{CO}_{3}$ was placed in the upper lids of each Petri plate along with uninoculated control. The plates were sealed with parafilm and incubated at $28+1^{\circ} \mathrm{C}$ for 4 days and observed for colour change from yellow to brown for putative $\mathrm{HCN}$ production.

\section{Qualitative test for IAA production}

A modified agar plate assay was used for qualitative estimation of IAA production by
Pseudomonas isolates (Shrivastava and Kumar, 2011). Luria Bertani Agar plate containing $100 \mu \mathrm{g} / \mathrm{ml}$ of tryptophan was prepared and poured in Petri plates. After solidification, cavities of $5 \mathrm{~mm}$ diameter and $0.2 \mathrm{~cm}$ depth were made by a sterile cork borer. Each cavity is filled with $50 \mu 1$ of overnight grown culture and incubated at $30^{\circ} \mathrm{C}$ for 24 hours. After overnight growth, the cavities are filled with two drops of Salkowski reagent. The development of pink colour after addition of Salkowski reagent was considered positive for IAA production.

Evaluation of Pseudomonas species for their growth promoting activity on sugarcane seedlings

Single node setts of sugarcane variety, 87A 298 , were soaked in a solution $\left(10^{9} \mathrm{cfu} / \mathrm{ml}\right)$ of Pseudomonas species for one hour and planted in portrays containing a mixture of cocopit and vermicompost. The setts soaked in water for one hour served as control. Five replications were maintained for each treatment. Germination percentage was recorded 30 days after sowing and the seedling vigor index (SVI) was calculated as per the formula, SVI = Germination percentage X Seedling length (Abdul-Baki and Anderson, 1973).

\section{Results and Discussion}

\section{Isolation and identification of rhizosphere bacteria}

All the bacterial isolates were found to be Gram negative, rod shaped, catalase positive with polar flagella. Nathan et al., (2013) described plant growth promoting bacteria (PGPB) of the genus Pseudomonas as Gram negative rod shaped bacteria with a positive reaction for catalase and oxidase tests. The bacterial isolates were identified as bacteria of the genus, Pseudomonas by amplifying the 
DNA with Pseudomonas specific primers, Psmn 289 and Psmn 1258. The electrophoresis of PCR amplified products had produced an amplicon of $957 \mathrm{bp}$ confirming the bacteria as Pseudomonas species. The elite Pseudomonas species, based on antagonistic ability against C. falcatum, was further identified to species level by partial sequencing of amplified products. The NCBI blast analysis revealed the identity of the elite Pseudomonas species as $P$. putida and designated as $P$. putida strain AKP1 (KX758438).

\section{Antagonistic activity against $C$. falcatum}

The Pseudomonas isolates were tested for their antagonistic activity against $C$. falcatum by dual culture method. Most of the Pseudomonas isolates tested (Table 1) were found inhibitory to the mycelial growth of $C$. falcatum under in vitro conditions. Highest inhibition $(69.23 \%)$ of the test pathogen was recorded with Pseudomonas putida strain AKP1 isolated from the rhizosphere of sugarcane clone, CoV 92102 (Fig. 1). This was followed by Pseudomonas species isolated from CoA13326 and 2001A 63 with an inhibition of 54.23 and 48.58 per cent, respectively. Least inhibition of mycelial growth of $C$. falcatum was recorded with the Pseudomonas isolated from the rhizosphere of 87A 298.

Hassan et al., (2011) evaluated bacterial strains isolated from sugarcane rhizosphere against $C$. falcatum and reported that Pseudomonas putida strain NH-50 (EU627168) reduced red rot severity by 44$60 \%$ in different field conditions and attributed the pathogen suppressing ability of the isolates to the production of various extracellular metabolites and diffusible antibiotics. The biocontrol abilities of Pseudomonas spp. depend essentially on aggressive root colonization, induction of systemic resistance in the plant, the production of diffusible or volatile antifungal antibiotics (Haas and Keel, 2003) and enzymes that degrade pathogen cell walls and hydrogen cyanide production (Ahmad and Kibret, 2014).

\section{Screening for growth promoting traits}

Biochemical characterization of Pseudomonas isolates for the production of enzymes revealed that all the isolates could produce catalase as evidenced by the production of effervescence on addition of hydrogen peroxide. Most of the isolates produced protease except the isolates retrieved from the rhizosphere of the sugarcane clones, CoA13324 and CoA13326. All the isolates tested have produced hydrogen cyanide (Fig. 2 ) as evidenced by the change in color of the filter paper from yellow to brown (Table 2).

$\mathrm{HCN}$ production was attributed as one of the factors for biological control of plant diseases by fluorescent Pseudomonads due to the induction of plant resistance against certain pathogens. Stutz et al., (1986) highlighted that cyanide secreted by Pseudomonas fluorescens strain CHAO played a role in the suppression of black root rot of tobacco (Thielaviopsis basicola).

Though, all the Pseudomonas isolates produced HCN, only some of the isolates could inhibit the mycelial growth of $C$. falcatum. The efficacy of bacterial strains against $C$. falcatum depends upon the pathotype of $C$. falcatum. Malathi et al., (2008) reported that the Pseudomonas fluorescens isolates, ARR1G and VPT4, were found effective against tropical pathotypes of C. falcatum and the isolate FP7 showed moderate effect against all the pathotypes. The antagonistic potential of Pseudomonas spp. was found to be dependent on the virulence of the pathotypes. 
Table.1 In vitro evaluation of rhizospheric bacteria (Pseudomonas sp.) of sugarcane in inhibiting mycelial growth of Colletotrichum falcatum

\begin{tabular}{|c|c|c|}
\hline SI. No. & Treatment & $\begin{array}{l}\text { Per cent inhibition of } \\
\text { mycelial growth }\end{array}$ \\
\hline 1 & Pseudomonas species (CoA13326) & $54.23(47.41)^{*}$ \\
\hline 2 & Pseudomonas species (2001A63) & $48.58(44.16)$ \\
\hline 3 & Pseudomonas species (87A298) & $1.41(6.82)$ \\
\hline 4 & Pseudomonas species (CoA13324) & $35.68(36.66)$ \\
\hline 5 & Pseudomonas species (Co6907) & $46.00(42.68)$ \\
\hline 6 & Pseudomonas species (CoA13326) & $46.71(43.10)$ \\
\hline 7 & Pseudomonas species (Co V92102) & $69.23(56.30)$ \\
\hline \multirow[t]{4}{*}{8} & Pseudomonas species (CoA13322) & $43.67(41.35)$ \\
\hline & $\mathrm{CD}(\mathrm{P}=\mathbf{0 . 0 5})$ & 1.934 \\
\hline & $\operatorname{SEm}( \pm)$ & 0.646 \\
\hline & $\mathrm{CV}$ & 3.161 \\
\hline
\end{tabular}

*Figures in the parenthesis are angular transformed values

Table.2 Evaluation of native Pseudomonas spp. for plant growth promoting traits

\begin{tabular}{|c|c|c|c|c|c|c|}
\hline $\begin{array}{l}\text { Sl. } \\
\text { No. }\end{array}$ & Treatment & $\begin{array}{c}\text { Catalase } \\
\text { production }\end{array}$ & $\begin{array}{l}\text { Protease } \\
\text { activity }\end{array}$ & $\begin{array}{c}\text { HCN } \\
\text { production }\end{array}$ & $\begin{array}{c}\text { IAA } \\
\text { production }\end{array}$ & $\begin{array}{c}\text { Phosphate } \\
\text { solubilizing } \\
\text { activity }\end{array}$ \\
\hline 1 & $\begin{array}{l}\text { Pseudomonas sp. } \\
\text { (CoA13326) }\end{array}$ & + & + & + & + & - \\
\hline 2 & $\begin{array}{l}\text { Pseudomonas sp. } \\
\text { (2001A63) }\end{array}$ & + & + & + & - & - \\
\hline 3 & $\begin{array}{l}\text { Pseudomonas sp. } \\
\text { (87A298) }\end{array}$ & + & + & + & - & + \\
\hline 4 & $\begin{array}{l}\text { Pseudomonas sp. } \\
\text { (CoA13324) }\end{array}$ & + & - & + & - & - \\
\hline 5 & $\begin{array}{l}\text { Pseudomonas sp. } \\
\text { (Co6907) }\end{array}$ & + & + & + & + & - \\
\hline$\overline{6}$ & $\begin{array}{l}\text { Pseudomonas sp. } \\
\text { (CoA13326) }\end{array}$ & + & - & + & + & - \\
\hline 7 & $\begin{array}{l}\text { Pseudomonas } \\
\text { putida AKP1 (Co } \\
\text { V92102) }\end{array}$ & + & + & + & + & + \\
\hline 8 & $\begin{array}{l}\text { Pseudomonas sp. } \\
\text { (CoA13322) }\end{array}$ & + & + & + & - & - \\
\hline
\end{tabular}

(+) Positive, (-) negative 
Table.3 Seedling vigour index of sugarcane seedlings as influenced by sett bacterization with Pseudomonas species

\begin{tabular}{|l|l|c|}
\hline SI. No. & Treatment & Seedling vigour index \\
\hline 1 & Pseudomonas species (CoA13326) & 1860 \\
\hline 2 & Pseudomonas species (2001A63) & 1260 \\
\hline 3 & Pseudomonas species (87A298) & 776 \\
\hline 4 & Pseudomonas species (CoA13324) & 800 \\
\hline 5 & Pseudomonas species (Co6907) & 1400 \\
\hline 6 & Pseudomonas species (CoA13326) & 1480 \\
\hline 7 & Pseudomonas putida AKP1 (Co V92102) & 1880 \\
\hline 8 & Pseudomonas species (CoA13322) & 1100 \\
\hline 9 & Control & 608 \\
\hline
\end{tabular}

Fig.1 In vitro inhibition of mycelial growth of Colletotrichum falcatum by Psudomonas putida isolate AKP 1

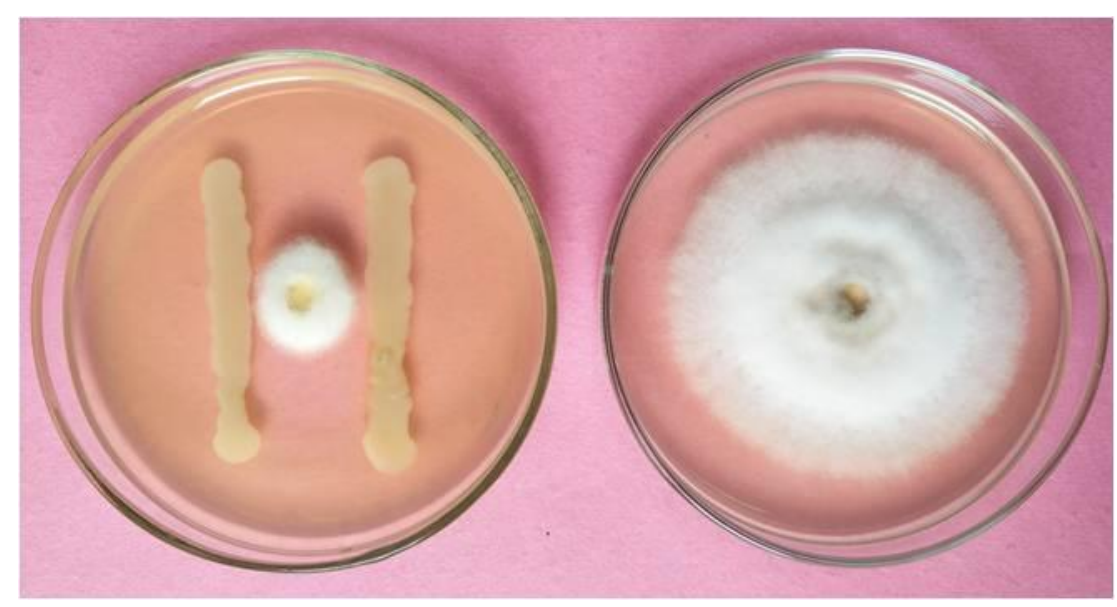

Fig.2 IAA and HCN production by Psudomonas putida isolate AKP 1

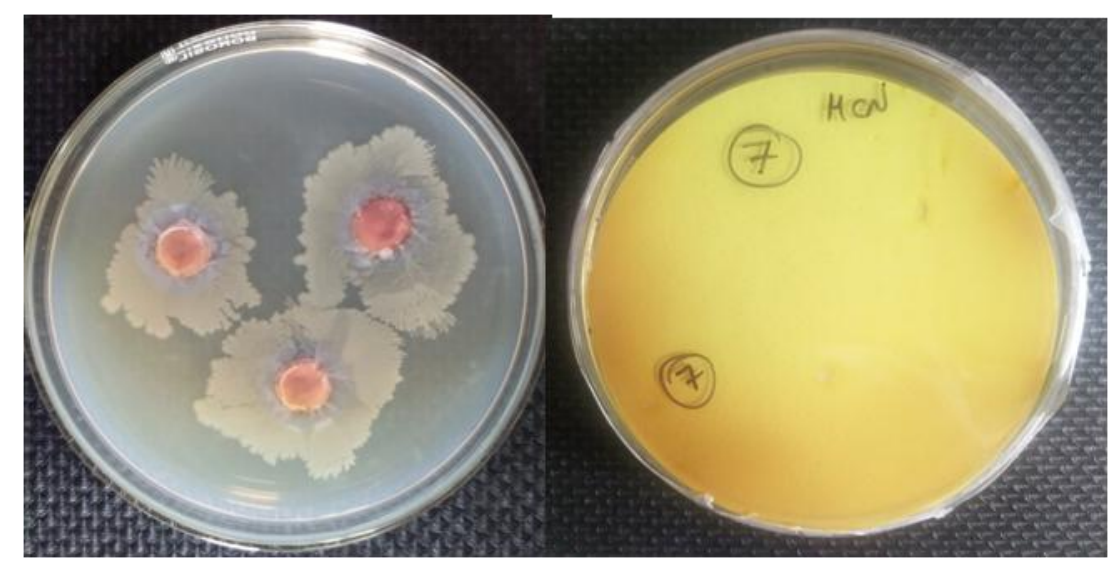


In IAA agar plate assay, pink zone was observed around the cavities in which the Pseudomonas spp. isolated from the rhizosphere of the sugarcane clones, CoA13326, Co6907, CoA13326 and CoV92102 (Fig. 2), were inoculated indicating the ability to produce IAA in the presence of tryptophan. Only few isolates could solubilize phosphate as shown by the formation of clear halos around the point of inoculation. IAA biosynthesis has been correlated with stimulation of root proliferation by rhizosphere bacteria, which enhanced uptake of nutrients by the associated plants (Lifishitz et al., 1987).

\section{Effect of sett bacterization on seedling vigour index}

Soaking the single node setts in bacterial suspension for one hour prior to planting in portrays enhanced sett germination and seedling vigour (Table 3) compared to control. Seedling vigour index was higher when the setts were treated with $P$. putida strain AKP1 (1880) and the Pseudomonas species isolated from the rhizosphere of CoA13326 (1860) compared to all other treatments. The seedling growth increase caused by sett bacterization with Pseudomonas species qualifies them as PGPR. Plant growth promotion by Pseudomonas species was related to the production of phytohormones like auxins (Bharucha et al., 2013), gibberellins (Kapoor et al., 2016) and cytokinins (Grobkinsky et al., 2016). Microorganisms inhabiting the rhizosphere of plants utilize the rich source of substrates from the roots and are expected to synthesize and release phytohormones as secondary metabolites (Berendsen et al., 2012) that controls many important physiological processes like cell enlargement and division, tissue differentiation and responses to light and gravity (Lambrecht et al., 2000). Plant growth promoting rhizobacteria (PGPR) have beneficial effects on plants which have been variously attributed to their ability to produce various compounds including phytohormones, organic acids and siderophores, to fix atmospheric nitrogen, to solubilize soil phosphate, to produce antibiotics that suppress deleterious microorganisms (Glick, 1995).

In our study, $P$. putida strain AKP1 isolated from the rhizosphere of sugarcane clone, $\mathrm{CoV}$ 92102 was found superior to all other isolates in having high inhibitory effect against $C$. falcatum besides its ability to solubilize inorganic phosphate and to produce catalase, protease, HCN, and IAA. Overall, our results suggested the scope and potentiality of $P$. putida strain AKP1 in inhibiting mycelial growth of $C$. falcatum besides plant growth promotion. Our future studies are directed in establishing the endophytic nature, if any, of $P$. putida strain AKP1 in sugarcane and in confirming the antagonistic activity on $C$. falcatum in greenhouse and field besides plant growth promoting activities.

\section{References}

Abdul-Baki, A. and Anderson, J.D. (1973). Vigor determination in soybean seed by multiple criteria. Crop Science 13: 630633.

Ahmad, M. and Kibret, M. (2014). Mechanisms and applications of plant growth promoting rhizobacteria: Current perspective. Journal of King Saud University-Science 26, (http://dx.doi.org/10.1016/j.jksus.2013.0 5.001).

Bakker, A.W. and Schippers B. (1987). Microbial cyanides production in the rhizosphere in relation to potato yield reduction and Pseudomonas spp. mediated plant growth stimulation. Soil Microbiology, ecology and 
Biochemistry 19: 451-457.

Berendsen, R.I., Pieterse, C.M. and Bakker, P.A. (2012). The rhizosphere microbiome and plant health. Trends in Plant Science 17(8): 478-486.

Bharucha, U., Patel, K. and Trivedi, U.B. (2013). Optimization of Indole acetic acid production by Pseudomonas putida UB1 and its effect as Plant growth promoting rhizobacteria on mustard (Brassica nigra). Agricultural Research 2(3): 215-221

Glick, R.B. (1995). The enhancement of plant growth promotion by free living bacteria. Canadian Journal of Microbiology 41: 109-117.

GOI. (2015). Price policy for sugarcane: 2016-17 sugar season. Commission for Agricultural Crops and Prices. Department of Agriculture and Cooperation, Ministry of Agriculture, Government of India, New Delhi, 80

GOI. (2017). Directorate of Economics and Statistics, Department of Agriculture, Cooperation and Farmers welfare, Ministry of Agriculture and Farmers welfare, Government of India, (http://eands.dacnet.nic.in).

Grobkinsky, D.K., Tafner, R., Moreno, M.V., Stenglein, S.A., Garcia de-Salamone, I.E., Nelson, L.M., Novak, O., Strnad, M., Van der Graaff, E., Roitsch, T., 2016. Cytokinin production by Pseudomonas fluorescens G20-18 determines biocontrol activity against Pseudomonas syringae in Arabidopsis. Scientific Reports-Nature 6, 23310 DOI: $10.1038 /$ srep23310

Haas, D. and Keel, C. (2003). Regulation of antibiotic production in root colonizing Pseudomonas spp. and relevance for biological control of plant disease. Annual review of Phytopathology 41: 117-153.

Hassan, M.N., Afghan, S. and Hafeez, F.Y. (2011). Biological control of red rot in sugarcane by native pyoluteorinproducing Pseudomonas putida strain NH-50 under field conditions and its potential modes of action. Pest Management Science 67: 1147-1154.

Hassan, M.N., Afghan, S. and Hafeez, F.Y. (2011). Biological control of red rot in sugarcane by native pyoluteorinproducing Pseudomonas putida strain $\mathrm{NH}-50$ under field conditions and its potential modes of action. Pest management science 67(9): 1147-1154.

Kannan, N., 2002. Laboratory manual in general microbiology. Panima Publishing corporation, New Delhi, India.

Kapoor, R., Soni, R. and Kaur, M. (2016). Gibberellins production by fluorescent Pseudomonas isolated from rhizospheric soil of Malus and Pyrus. International Journal of Agriculture, Environment and Biotechnology 9(2): 193-199.

Lambrecht, M., Okon, Y., Brock, A.V. and Vanderleyden, J. (2000). Indole-3-acetic acid: a reciprocal signalling molecule in bacteria-plant interactions. Trends in Microbiology 8: 298-300

Lifishitz, R., Kloepper, J.W. and Kozlowski, M. (1987). Growth promotion of canola (rapessed) seedlings by a strain of Pseudomonas putida under gnotobiotic conditions. Canadian Journal of Microbiology 33: 390-395.

Malathi, P., Padmanabhan, P., Viswanathan, R. and Mohanraj, D. (2008). Interaction between Colletotrichum falcatum pathotypes and biocontrol agents. Archives of Phytopathology and Plant Protection 41(5): 311-317.

Pikovaskaya, R.I. (1948). Mobilization of phosphorous and soil in connection with the vital activity of some microbial species. Mikrobiologii 17: 362-370.

Rao, G.P. (2004). Sugarcane Pathology. Oxford and IBH Publishing company, 
UK 2.

Sambrook, J. and Russell, D.W. (2001). Molecular cloning: A laboratory manual. Volume 1, Cold Spring Harbor Laboratory Press, New York, USA, 2344

Shrivastava, U.P. and Kumar, A. (2011). A simple and rapid plate assay for the screening of Indole-3-acetic acid (IAA) producing microorganisms. International Journal of Applied Biology and Pharmaceutical
Technology 2(1): 120-123.

Singh, V., Srivastava, R.L., Awasthi, S.K. and Joshi, B.B. (2008). Biological control of red rot disease of sugarcane through Trichoderma harzianum and Trichoderma viride. Indian Phytopathology 61(4): 486-491.

Stutz, E.W., Defago, G. and Karen, H. 1986. Naturally occurring fluorescent pseudomonads involved in suppression of black root rot of tobacco. Phytopathology 76: 181-185.

\section{How to cite this article:}

Kishore Varma, P., K.V.K. Kumar, M. Suresh, N. Raja Kumar and Sekhar, V.C. 2018. Potentiality of Native Pseudomonas spp. in Promoting Sugarcane Seedling Growth and Red Rot (Colletotrichum falcatum went) Management. Int.J.Curr.Microbiol.App.Sci. 7(02): 28552863. doi: https://doi.org/10.20546/ijcmas.2018.702.348 